\title{
The Play in the Context of Early Childhood Education in the View of Nurseries Professionals
}

\author{
Fabiana Cristina Frigieri de Vitta1,2, Claudia R. M. Giroto, 1 , Rosane Michelli de Castro ${ }^{3}$, \\ Débora Aleixo Campanhã ${ }^{4}$, Maria Clara Nassif de Souza ${ }^{4}$, Bárbara D. Solana ${ }^{4}$, \\ Carla F. M. Novaes ${ }^{4}$, Joice Emanuele Munhoz Cicilino ${ }^{2}$, Alberto de Vitta ${ }^{5}$ \\ ${ }^{1}$ Department of Especial Education, Faculty of Philosophy and Sciences (FFC), UNESP, Marília, Brazil \\ ${ }^{2}$ The Program Graduate of School Education, Faculty of Science and Letters (FCLAR), UNESP, Araraquara, Brazil \\ ${ }^{3}$ Department of Didactics, The Program of Postgraduate on Education, Faculty of Philosophy and Sciences (FFC), \\ UNESP, Marília, Brazil \\ ${ }^{4}$ Faculty of Philosophy and Sciences (FFC), UNESP, Marília, Brazil \\ ${ }^{5}$ The Program of Physiotherapy, Universidade Sagrado Coração (USC), Bauru, Brazil \\ Email: fabianavitta@gmail.com, claudia.mosca@marilia.unesp.br, rosanemichelli@marilia.unesp.br, \\ debora.terapeutaocup@gmail.com, ma.nassif@hotmail.com, badomettsolana@hotmail.com, \\ cfmartini@hotmail.com, joicecicilino@gmail.com, albvitta@yahoo.com.br
}

Received 17 February 2015; accepted 2 April 2015; published 7 April 2015

Copyright (C) 2015 by authors and Scientific Research Publishing Inc.

This work is licensed under the Creative Commons Attribution International License (CC BY). http://creativecommons.org/licenses/by/4.0/

(c) (i) Open Access

\section{Abstract}

The activities carried out with the child 0 - 2 years, as the play are vitals for the development of perceptions, movements, postures and intelligence contributing to the acquisition of psychomotor and cognitive skills. The family has played an important role in providing this tool, but today, in Brazil, the children in this age group have attended the Early Childhood Education institutions. Thus, the objective of this research was to determine the meaning given by professionals from the nursery to the activities to play of the age group 0 - 2 years. Participated a total of 128 professionals working in municipal nurseries of a medium-sized city of São Paulo. They were asked about the importance of play and toy for children 0 - 2 years and how it is offered in the nursery routine. The answers were analyzed based on qualitative data analysis technique and enhanced with concepts of thematic analysis. They were organized in themes importance of play; proposals for toys and games; organization of time, space and materials for activities to play; participation in the activities of play. The results indicate that: 1) the activity of play is considered important by the participants for both the development and the learning; 2) teachers are responsible for organizing this activity focused on educational planning; 3 ) they report that playing at this age is difficult, especially with the smaller, because of the nursery routine of the organization. Therefore, this work 
contributes to the design of the activities of play, more suitable to the needs of the public attended, aiming at the global development of the baby.

\title{
Keywords
}

\author{
Playing, Activities, Nursery, Family
}

\section{Introduction}

Because socio-cultural changes that, in Brazil, led families to reorganize and women to take more and more activities outside home, children in early years attended education institutions. Macarini, Martins and Vieira (2009) emphasize the important relationship between family and school in this age group, because the baby is directly influenced by the relationships established between their biological condition and the environment, and the quality of the activities in which engages fundamental to its development (Vitta, 2004; Almeida \& Valentini, 2010; Bonome-Pontoglio \& Marturano, 2010).

In Brazil, there are a lot of families considered at-risk, low socioeconomic status. Factors associated with this situation, such as malnutrition, educational and social deprivation, family problems are considered crucial to the development of the child (Pilz \& Schermann, 2007). Thus, educational institutions can offer the child differentiated experiences, promoting learning skills and competencies.

This change in baby's environment for the establishment of early childhood education did the baby organize your routine based on the activities developed in the home and in the family. There is still much debate about the nursery function-care and education. The activities of care (hygiene, food, clothing), to be held with all the children end up taking much of the time of professionals. The play is performed freely in the intervals of care activities and toys not always suitable for age (Vitta \& Emmel, 2004), but should be recognized as a right of the child to education and be integrated in this age group.

The organization's activities routine, taking into account the child's learning and development needs is an important gap between the school and the family. In other words, the activities, and the whether considered care or education should be structured to promote the child's skills, and by its purpose and planning, differentiate those made at home by the family.

Several documents published in Brazil in order to help organize activities in educational institutions, and here highlighted the play. The National Curriculum Guidelines for Early Childhood Education (Brazil, 2010), the banter and interactions resulting from them are considered the guiding principles for the work to be developed in all areas of knowledge among small children. In the National Curriculum Reference for Early Childhood Education-RCNEI (Brazil, 1998), the game is considered as one of the fundamental principles defended as a right, a particular form of expression, thought, communication and interaction among children.

Importantly, the adult intermediation in the activity of play is of paramount importance. Your participation and intervention during play are extremely important in shaping the child (Marques \& Bichara, 2011). Takadori (2012: p. 50) writes,

On the one hand, the child who plays his gesture intended the world to someone welcome him: "What are we going to play today?”. On the other, a human face that witness and recognizes your creative gesture and gives possibilities for entry to the culture from which it is unique in its existence: "Let’s play hide."

Meneghini and Carvalho (2003) emphasize that it is important that the teacher's training had opportunity to connect with the various possibilities of space organization and its influence on the child's activity, since it has autonomy for exploration. A study by Bonome-Pontoglio and Marturano (2010) found that thirty minutes a day of playful educational activities with adult mediation may be sufficient to promote the development of children skills in two years.

From the initial experiments, the activity will structuring and will gaining meanings, especially if the adult participation is effective. To Figueiredo (2009), adults, most often do not recognize the importance of children's play, which is seen as a mere hobby, devoid of meaning.

It is important to consider that the understanding that the nursery workers have the play, as well as toys, their function, application and practice with the use of these objects in the nursery daily life are critical in the organi- 
zation and development of these activities in the nursery routine.

Considering this point, this study aimed to verify the meaning assigned by nursery professionals to activities to play with the age group 0 - 2 years in the area of early childhood institutions.

\section{Method}

The research is part of a program developed with the City Department of Education (SME) of a medium-sized city in the interior, which includes extension projects, research and continuing education courses, organized jointly by the Group of Studies and Research Activity and Child Development (GEPADI) and the division of Early Childhood Education-nurseries. Was approved by the Research Ethics Committee of UNESP-protocol 0011/2000.

The participants were invited to participate in the survey at the beginning of training courses offered by SME in the years 2012 and 2013. Thus, the sample was for convenience, based on the interest of the participants. At the beginning of the first meeting were informed about the project, its objectives and procedures and then invited to sign the free and informed consent.

A total of 128 professionals working in educational institutions, including teachers and auxiliary school development (ADE). The teachers were mostly training in higher education or high school Magisterium and ADE, only high school, and some were attending a degree in pedagogy.

To perform the data collection were distributed among the participants, a protocol of questions based on the objective of the research, bibliographic references in the area and on research carried out by De Vitta (2004). The respondents could take the protocol and return home responded a week later. The questions were about the importance of play and toy for children 0 - 2 years and how it is offered in the nursery routine. In this item, met in a frame: 1) the measures, as was the organization of materials and children for the activity, 2) content/ objectives, or why the activity is performed in contributing, 3) materials useds and adequacy thereof, 4) space used and their adequacy, 5) instructions given to children to carry out the activity, 6) participation of children, explaining how this occurs.

The answers were analyzed based on qualitative data analysis technique proposed by Bryman and Burgess (1999) and enhanced with concepts of thematic analysis proposed by Minayo (2008). Thus, the collected data were organized and analyzed. The presence of certain themes led to the formation of relevant structures, reference values and behavioral models present or underlying the discourse (Minayo, 2008).

\section{Results}

Results were organized by themes: importance of play; proposals for toys and games; organization of time, space and materials for activities to play; participation in the activities of play.

The activity of the play was considered important by teachers, especially for the learning of children and stimulation of its development. Stood out in the responses the relationship between play, imagination, communication, language and writing, creativity and motor coordination. In many speeches there was greater concern for school learning. The objectives listed for these activities are defined by the teacher, with interference in some cases the educational coordinator and director. Some teachers mentioned are based on the syllabus given by the Board of Education. But none said exactly what were these goals.

According to the participants, there are aspects that affect the definition of these objectives, such as age, curriculum proposal (which translates into a pedagogical proposal), the child's needs, the number of children, the availability and suitability of toys, aspects to be evaluated, pedagogical meeting settings and programming of the day.

The activities to play are scheduled to play according to the axes to be worked per week, objectives, expectations, content, through the approval of the coordinator. This weekly program is designed as a "semanário" or "weekly" and is built on the school's annual plan. The document, given by the Department of Education, which teachers refer to base preparation of the annual planning and the weekly is the RCNEI (Brazil, 1998).

As for the steps taken to carry out the activity of play, that is, how the planning is put into practice, the answers were concentrated in the organization of physical space and materials and in the previous explanations that can be given to children on how to be the activity.

Regarding the organization of the environment and materials, subject contemplated by another question, it was established that she translates for cleaning the space, furniture arrangement, selection of materials to be used and the needs of play. 
As for the materials used, it was found from typical materials of school, linked directly to the design and writing, as well as those that can promote sensory and motor stimulation of the child, in the different activities to be proposed, which also appear in "jokes". Most participants said to be suitable for the age, but many of them cook up the materials precisely to optimize them. However, it is emphasized that the presence of materials and toys do not guarantee that the activity is beneficial for children. It all depends on how it is conducted by the adult, how is offered and what the implicit goals.

Many participants expressed concern over the size of the toy, being interested in the care of the child. Some had trouble saying the right play, not knowing what would fit in and play as a baby can play. It was revealed very difficult to play with children 4 - 9 months. The teachers have more ease in elaborate games with larger, than with smaller ones.

Regarding the participation of the professional in the games, there was difference of opinion between the participants, some feel that the teacher must always be with the child, while others believe that the most effective is to mix two moments, the living together and leaving the game free. Some commented on the teacher being the model, the example for the child.

As for the children, participation is seen from the results, that is, how much more involved, more functions the child will develop. Some people said that the child's participation is to help keep the toys. Others were, again, the difficulty of participation of smaller babies, which happens only by looking.

\section{Discussion}

While there is recognition of professional importance of playing in the age group 0 - 2 years, there is an explicit difficulty thinking in these activities, and the smaller the child, the greater the difficulty, these data found in the study by Vitta and Emmel (2004). Several factors contribute to this. One of them refers to the age of the children-babies have less autonomy and independence, that is, depend on adults to be placed in a more active stance. His play are more timid, less action on objects. This aspect directly affects the proposals made by professionals, that is, with a baby play? What kind of material can be used? How to organize the activities of play? What for? How the child will attend? All these issues end up appearing in the analysis of the answers, because there is no clarity on how to organize the play in the nursery.

The situation ends up even more difficult by infrastructure problems, purchase of unsuitable materials and the need to create objects with scraps. Obviously there are no problems in this situation, since she is not the only way to provide activities for children to play $0-2$ years. This child is in full development of motor, cognitive and social skills and needs of structuring time and space and material resources to be used with specific learning objectives for this age group. As time passes, the activities are easier to play, just by the gain of autonomy and independence, which are reflected in the reduction of adult interference to keep the child in an appropriate physical state. Moreover, it seems more reasonable to think of play and objects-toys-which can be stimulating for the child, as she gets older.

In the common sense there is an idea that the play is natural of child and that happens all the time and this allows even the understanding that when she was with a material in hand, she's kidding, can occur in the range of care activities or random. However, as it is an educational institution, it is important to have a plan for these activities and which are contained in the educational program of the school, having thus each stage of development and contributing to the development of their autonomy (Rosa, 2001).

Oliver (2012) agree that there should be a schedule of recreational activities, with the play being inserted in the school pedagogical project. Several documents published by the Ministry of Education (MEC) reinforce this idea. According to the National Curriculum Reference for Early Childhood Education:

Material resources understood as furniture, mirrors, toys, books, pencils, paper, paints, brushes, scissors, glue, clay, clay, the most diverse games, blocks for buildings, scrap material, clothes and rags to play etc. should have mandatory attendance in educational institutions of carefully planned way (Brazil, 1998: p. 69).

There is a difference between a spontaneous play, the child is able to perform, and play directed by an adult, identified as high quality. In a children's institution is necessary, more than providing the games and toys, planning of physical space, as well as intentional actions which promote quality play (Brazil, 2012).

According to Iza and Mello (2009: p. 283) the teacher should move away from "the danger of alienation of this practice in early childhood education," taking care to organize activities with intentionality and not leaving 
the children with toys to learn "by itself".

The interaction of adult is fundamental for the development of play linked to objectives and pre-programmed content, considering the characteristics of children and the institution itself. It is this participation that does not let the play be random, to "will God" and that allows the observation of the progress on the sensory-motor and social skills.

Adults are responsible for the organization of time and space, as well as the materials and their disposal in the environment where the child is. This function is responsible for the group's disposal and should be done based on educational goals and possibilities of the institution, adapting the activity to optimize their use. Navarro and Prodocimo (2012) agree with the need for a conscious professional involvement with the children, and emphasize the value of experimentation due to the play and the important role of teacher to interfere with the quality of play of the students.

With the planned participation of the professional no better interaction with the environment, with small children encouraged to remain in increasingly autonomous and gradually positions, begin to dominate the handling of different objects (Vitta \& Vitta, 2012; Paniagua \& Palacios, 2005; Organization for Cooperation and Economic Development, 2002).

The child is participating in its development through their relationships with the physical and social environment. It explores, discovers and initiates actions that encourage a series of discoveries and give you immediate answers; select partners, objects and areas for their activities and the teacher becomes the most responsible for the structuring and restructuring of the spaces offered to them (Meneghini \& Carvalho, 2003).

Playing enables situations that favor child learning, providing more complex levels of development. It is of vital importance in the development of perceptions, movements, postures and intelligence of the child contributing to the development of psychomotor and cognitive skills (Jesus, 2010). It also promotes solidarity, cultural development, establishment of mutual affection and social interaction, incorporating new values and developing friendships among children (Jesus, 2010). It is from the play that the child manages their relationship with each other and with the world, assimilates the meanings of human actions and appropriates them; tests your autonomy and will constitute as a subject, allowing learn about reality, becoming able to develop their creative potential (Siaulys, 2005).

Almeida and Valentini (2010) highlight the importance of the activities carried out with the babies for the formation of your memories, which integrated the new experience provides learning. According to them "an environment rich in sensory experiences (afforded by family members, educators and therapists) is vital for child development” (Almeida \& Valentini, 2010: p. 16).

Within of the children's institution is the teacher who helps to structure the field of play in children's lives by organizing their structural basis, offering certain objects, costumes, toys or games, while determining and arranging the space and the time to play (Brazil, 1998). For this to occur, teachers need to know the child's development process, and also the steps that she must conquer (Almeida \& Casarin, 2002).

This is the main difference between the school and the family-planning activities with educational objectives to promote learning and development. Study published by the Organisation for Economic Cooperation and Development (OECD) highlights the need to share education and early childhood care (ECEC) between the family and the government (Organization..., 2002). The document also highlights the importance of the relationship between parents and professionals for "continuity in learning and experiences of children" between school and home (p. 173).

The professionals caring for children 0 - 2 years must be prepared to work with this age group, knowing add to the activities, aspects that promote child development. However, the data clearly show the influence of duality care $\times$ educate in the speeches of the participants and made explicit when asked about the duties performed. This discussion is not new, either, exclusive of the Brazilian reality (Vitta \& Vitta, 2012; Campos et al., 2011). It is difficult to think in nurseries as part of basic education and should fall to an educational philosophy, with activities that necessarily being care (hygiene, food and clothing) should include educational objectives and be placed in context of learning and global development the child.

\section{Final Thoughts}

The data showed that despite the resistance to accepting the nursery as part of the child's education, professionals who participated in this research attach to this objectives institution linked to global development. In this perspective, the toy and the play gain strength, representing possibilities of providing activities of interest and contribute to the stimulation of motor, cognitive and social in childhood, providing a different experience of- 
fered by the family.

However, the time and space for play are still a problem to be solved in early childhood institutions working with children 0 - 2 years because the activities of care are priorities in the routine organization and the purchase of materials. Participants seem to have concern for the physical and material resources to provide the play but have difficulty in naming as they are organized and how are proposed activities for the children. It is difficult to explain the play with the younger children, as well as the suitability of toys and games. It is clear that, over time, children grow older, the activities of care and decrease the chances of play increase, with more elaborate and included in educational planning.

There is a clear need for a training job that allows professionals think about the issue and ways to play their educational role in a planned manner, meeting educational goals, inserted into lesson plans and teaching project. It is awarded to teachers this planning task, and in the halls of nurseries other professionals-assistants, trainees, attendants-have close contact to children in various situations and can provide the play order learning skills to own age. That is, it is necessary that the intervention through play, for all professionals working in nurseries, whether intentional and specific objectives, as it is through play that important in shaping the individual can be purchased at the initial stage of life

The presented final results contribute to the discussion concerning the organization of play in the nursery activities so there is stimulation of the child's overall development. Also, we affirm the need for an out more research and discussions, especially regarding the way to observe as it happens, truly, the game at this age group, as well as the efficiency of continuing education courses on the subject.

\section{References}

Almeida, C. S., \& Valentini, N. C. (2010). Integração de informação e reativação da memória: Impacto positivo de uma intervenção cognitivo-motora em bebês. Revista Paulista de Pediatria (Impresso), 28, 15-22. http://dx.doi.org/10.1590/S0103-05822010000100004

Almeida, D. M., \& Casarin, M. M. A. (2002). Importância do Brincar pra a Construção do Conhecimento na Educação Infantil. Santa Maria: Revista Educação Especial, No. 19. http://coralx.ufsm.br/revce/ceesp/2002/01/a6.htm

Bonome-Pontoglio, C. F., \& Marturano, E. M. (2010). Brincando na creche: Atividades com crianças pequenas. Estudos de Psicologia (Campinas), 27, 365-373. http://dx.doi.org/10.1590/S0103-166X2010000300008

Brasil (1998). Ministério da Educação e do Desporto. Secretaria de Educação Fundamental. Referencial curricular nacional para a educação infantil. Brasília: MEC/SEF.

Brasil (2010). Ministério da Educação. Secretaria de Educação Básica. Diretrizes curriculares nacionais para a educação infantil. Brasília: MEC, SEB.

Brasil (2012). Ministério da Educação. Secretaria de Educação Básica. Brinquedos e brincadeiras de creche: Manual de orientação pedagógica/Ministério da Educação. Secretaria de Educação Básica-Brasília: MEC/SEB.

Bryman, A., \& Burgess, R. G. (1999). Analyzing Qualitative Data. London: Routledge.

Campos, M. M., Esposito, Y. L., Bhering, E., Gimenes, N., \& Abucham, B. (2011). A qualidade da educação infantil: Um estudo em seis capitais brasileiras. Cadernos de Pesquisa, 41, 20-54.

http://dx.doi.org/10.1590/S0100-15742011000100003

Figueiredo, M. X. B. (2009). A corporeidade na escola: Brincadeiras, jogos e desenhos (6th ed.) Pelotas: Editora Universitária-UFPel.

Iza, D. F. V., \& Mello, M. A. (2009). Significado e sentido da atividade de brincadeira para professoras de educação infantil. Santa Maria: Educação, 34. http://cascavel.ufsm.br/revistas/ojs-2.2.2/index.php/reveducacao/article/view/240

Jesus, A. C. A. (2010). Como aplicar jogos e brincadeiras na educação infantil. Rio de Janeiro: Brasport.

Macarini, S. M., Martins, Gabriela, D. F., \& Vieira, M. L. (2009). Promovendo saúde e desenvolvimento na educação infantil: uma atuação da Psicologia. Paidéia (Ribeirão Preto), 19, 231-237. http://dx.doi.org/10.1590/S0103-863X2009000200011

Marques, R. L., \& Bichara, I. D. (2011). Em cada lugar um brincar: reflexão evolucionista sobre universalidade e diversidade. Estudos de Psicologia (Campinas), 28, 381-388. http://dx.doi.org/10.1590/S0103-166X2011000300010

Meneghini, R. \& Carvalho, M. C. (2003). Arranjo espacial na creche: Espaços para interagir, brincar isoladamente, dirigir-se socialmente e observar o outro. Psicologia: Reflexão e Crítica. Ribeirão Preto, 16, 367-378.

http://dx.doi.org/10.1590/S0102-79722003000200017

Minayo, M. C. S. (2008). O desafio do conhecimento: Pesquisa qualitativa em saúde (11th ed.). São Paulo: Hucitec. 
Navarro, M. S., \& Prodócimo, E. (2012). Brincar e mediação na escola. Revista Brasileira de Ciências do Esporte, 34, 633648. http://dx.doi.org/10.1590/S0101-32892012000300008

Oliver, G. C. (2012). A importância do brincar na educação infantil. Rio de Janeiro: Trabalho de conclusão de curso (Faculdade de Psicologia), Universidade Veiga de Almeida.

Organização para a Cooperação e o Desenvolvimento Econômico (2002). Educação e Cuidado na Primeira Infância: Grandes desafios. Brasília: UNESCO.

Paniagua, G., \& Palacios, J. (2005). Educação infantil: Resposta educativa à diversidade. Porto Alegre: Artmed Editora.

Pilz, E. M. L., \& Schermann, L. B. (2007). Determinantes biológicos e ambientais no desenvolvimento neuropsicomotor em uma amostra de crianças de Canoas/RS. Ciência e Saúde Coletiva, 12, 181-190. http://dx.doi.org/10.1590/S1413-81232007000100021

Rosa, R. T. D. (2001). Ensino de Ciências e Educação Infantil. In C. M. Craidy, \& G. E. P. S. Kaercher (Eds.), Educação Infantil: Pra que te Quero? (pp. 153-164). Porto Alegre: Artmed.

Siaulys, M. O. C. (2005). Brincar para todos. Brasília: MEC/SEESP.

Takadori, M. (2012). O brincar na Terapia Ocupacional: Um enfoque na criança com lesões neurológicas. São Paulo: Zagodoni Editora.

Vitta, F. C. F., \& Emmel, M. L. G. (2004). A dualidade cuidado × educação no cotidiano do berçário. Paidéia, Ribeirão Preto, 14, 177-189. http://dx.doi.org/10.1590/S0103-863X2004000200007

Vitta, F. C. F., \& Vitta, A. (2012). Promoção do desenvolvimento da criança no contexto educacional: O berçário. In L. O. Zaniolo, \& M. J. C. Dall'acqua (Eds.), Inclusão escolar: Pesquisando políticas públicas, formação de professores e práticas pedagógicas (pp. 141-162). Jundiaí: Paco Editorial. 